\title{
SMPD4 Gene
}

National Cancer Institute

\section{Source}

National Cancer Institute. SMPD4 Gene. NCI Thesaurus. Code C105035.

This gene is involved in ceramide biosynthesis. 